\title{
Memorialising the (Un)Dead Jewish Other in Poland: Spectrality, Embodiment and Polish Holocaust Horror in Władysław Pasikowski's Aftermath (2012)
}

\author{
Emily-Rose Baker \\ School of English, University of Sheffield, Sheffield S10 2TN, UK; erbaker1@sheffield.ac.uk \\ Received: 4 September 2019; Accepted: 20 November 2019; Published: 29 November 2019
}

\begin{abstract}
This article analyses the function and symbolic currency of Poland's recent literary and artistic motif of the returning Jew, which brings the nation's Jewish Holocaust victims back to their homes as ghosts, spectres and reanimated corpses. It explores the ability of this trope-the defining feature of what I call 'Polish Holocaust horror' - to cultivate the memory of complicitous and collaborative Polish behaviour during the Holocaust years, and to promote renewed Polish-Jewish relations based upon a working-through of this difficult history. In the article I explore Władysław Pasikowski's 2012 film Aftermath as a self-reflexive product of this experimental genre, which has been considered ethically ambiguous for its necropolitical treatment of Jews and politically controversial for its depiction of Poles as perpetrators. My analysis examines haunting as central to these popular cultural constructions of Holocaust memory-a device that has been used within the genre to mourn but also expel guilt for the previously forgotten or supressed dispossession and murder of Jews by some of their Polish neighbours.
\end{abstract}

Keywords: haunting; cultural memory; Holocaust fiction; Polish-Jewish relations; Jedwabne; spectrality; ghosts

\section{Introduction}

During the 2010 performance of the first quasi-fictional ${ }^{1}$ International Congress of the Jewish Renaissance Movement in Poland (JRMiP), held at Berlin's Hebbel am Ufer performance space, Israeli director and artist Yael Bartana issued a 'manifesto' pertaining to the group's hypothetical mission. Seeming to speak on behalf of a displaced yet returning Jewish population that once thrived in Poland, the manifesto stated: 'We plan no invasion. Rather we shall arrive like a procession of the ghosts of your old neighbours, the ones haunting you in your dreams, the neighbours you never had the chance to meet' (Bartana 2010). These lines self-reflexively tap into a highly emotive national Polish rhetoric of healing and haunting, of wounds and scars, and, perhaps most significantly, of neighbours-the title of Polish historian Jan T. Gross's 2000 study, which controversially exposed the complicity and collaboration of some Poles in the planned murder of their Jewish neighbours in the village of Jedwabne in the summer of 1941. Paradigmatic of a spate of popular fictional narratives about Jewish phantoms in the wake of Gross's book, Bartana's manifesto exposes precisely the function of Poland's new literary and artistic genre I shall henceforth name 'Polish Holocaust horror': to bring back the nation's deceased Jewish victims as a means of dealing with collective national guilt over Polish wartime behaviour.

1 The Jewish Renaissance Movement in Poland is a real political organisation that came out of Bartana's film trilogy And Europe Will Be Stunned (2007-2011), which impossibly calls for Poland's 3 million Holocaust Jews to return home. According to its website, also created by Bartana, the JRMiP is 'real in that [it] is composed of willing participants in an actual experiment; fictive in that this experiment entails imagining rather than reifying a different reality'. 
This article examines the function and symbolic currency of these contemporary cultural constructions of Holocaust memory via an analysis of the spectral and embodied remains disturbing the unnamed filmic universe of Władysław Pasikowski's Aftermath (2012). The film, which has been described by Pasikowski as a 'thriller' despite conforming to the generic conventions of Holocaust horror in Poland, is unusual in its representation of both intangible and bodily menace. Situating the trope of the returning Jew within vexed and ongoing national debates regarding Polish responsibility for the darker aspects of its wartime past, the article explores the timeliness of these experimental and affective modes of Holocaust memorialisation, which serve to undermine the revisionist historical policy consciously fostered by Poland's Law and Justice (PiS) party since their rise to power in 2015. Evident also in the works of Polish novelists Igor Ostachowicz and Piotr Paziński, playwright Tadeusz Słobodzianek and director Paweł Pawlikowski, the genre's simulated intergenerational Polish-Jewish encounters constitute an opportunity for Poland to confront the uncomfortable reality of Jewish murder and dispossession during the Holocaust years. They also, however, threaten to provide closure in relation to such anti-Jewish violence, which is re-enacted via the permanent suspension of the genre's Holocaust victims between life and death. As such, this article exposes the ethical ambivalence of the Jewish return in its necropolitical exploitation of the lived-a form of violence in and of itself that can be traced in various antisemitic tropes and mythologies, from the medieval to contemporary period.

\section{Polish Holocaust Horror}

Links between the aesthetic objectives of horror and Holocaust representation are not difficult to identify, especially if one considers the explicit and terror-inducing images of suffering and violence encountered in well-known Holocaust works like Schindler's List (1993) and Night and Fog (1956). While horror has been successfully explored in relation to Holocaust fiction elsewhere, in (Picart and Frank 2006; Lowenstein 2005), for instance, these works tend to adopt a western literary lens and are as such unable to address the specificity of horror as it manifests within recent Polish fiction and film. Closely examined in various literary and artistic contexts (see Lehrer, Sendyka, Dziuban, Waligórska and Blacker), the Jewish return has also received much critical attention in the last decade, especially by central and eastern European scholars in the fields of Holocaust and cultural memory studies. The relation of this motif to horror, however, has not yet been fully outlined, nor has its significance within Pasikowski's film.

In his influential essay 'Necropolitics', Achille Mbembe argues that the Foucauldian notion of biopower 'is insufficient to account for contemporary forms of subjugation of life to the power of death' (Mbembe 2003). In other words, biopower's focus on specific institutional forms of bodily regulation does not account for the existence of enslaved people, to use Mbembe's example, or indeed concentrationary subjects, whose proximity to death is a fundamental characteristic of their existence. Interminably caught in-between life and death, these shadowy figures bear witness to 'a phantomlike world of horrors and intense cruelty and profanity' in which they are 'kept alive but in a state of injury' (Mbembe 2003). Necropower does not consist in the right to make live or put to death, therefore, but rather in 'unique forms of social existence in which vast populations are subjected to conditions of life conferring upon them the status of living dead' (Mbembe 2003). In Holocaust contexts, the manifestation of necropower is most clearly embodied by the Muselmann-the term Giorgio Agamben borrows from Holocaust writers like Primo Levi to designate the living corpse of the concentration camp regime. Reduced to bare or necropolitical life through starvation, malnutrition and physical and psychological exhaustion, these zombie-like figures constituted the living dead in the camp world. Despite rarely resembling Muselmänner, supernatural and embodied figurations of the Jewish undead are at the heart of Polish Holocaust horror, so called, I argue, due to the inextricable link of the genre to the politics of national memory and identity in Poland, where shared experiences of Holocaust trauma have become a cornerstone of what it means to be Polish.

Jewish people have long been subjected to the kind of reduced humanity described by necropower, both within literature and the cultural imaginary. On the one hand, Jews have been cast as physically 
monstrous, zombified or proto-vampiric. On the other, they have also been conceptualised as supernatural or amorphous; as diasporic, wandering or exiled, their liminality signifying precisely the condition that, in its breaking down of corporeal reality and thus of 'borders, positions, rules', encodes Jews as ontologically other (Kristeva 1982). Polish Holocaust horror makes use of this necropolitical cultural practice, invoking the murdered Jewish neighbours of Polish perpetrators as displaced agents of haunting. The rhetoric of haunting is, as Zuzanna Dziuban points out, 'omnipresent' in recent academic Polish Holocaust discussion, owing to the space opened up for national reflection as well as Jewish memory after the fall of communism in 1989 (Dziuban 2014). With the Holocaust largely taking place in Nazi-occupied Poland, the notion of a Holocaust-haunted Poland refers to the nation's own 3,000,000 victims as well as its involvement in the murder of Polish Jews and the persistence of antisemitism here, which 'survived the war almost intact' (Ibid. 2014). Poland's recent Holocaust genre is primarily concerned with unveiling the latter through reimagining sites-typically mass graves, but also cemeteries and ghettos-repopulated by undead Jews of the past. These returning neighbours are inscribed within the rural, and sometimes urban, Polish landscapes characteristic of the genre, the former constituting spaces Aleida Assmann calls 'phantom sites' ${ }^{2}$ due to their concealed nature as the location of unatoned crimes (Assmann 2018).

The spatial dynamics of this genre, in which Holocaust topographies traumatised by their witness of Jewish killing are themselves animated by the presence of the undead, are thus particularly significant. Death is etched into these sites, which haunt the fictional universes of Polish Holocaust horror as much as the necropolitical subjects they embody. It is the genre's temporal framework, however, that facilitates its ability to disturb, shock or horrify. In its making-visible of that which was previously repressed, haunting entails a temporal inversion of the past. Avery F. Gordon argues that haunting is a 'frightening experience' precisely because 'it registers the harm inflicted or loss sustained by a social violence done in the past or in the present' (Gordon 2008). Mirroring the belated resurfacing of trauma, haunting thus has to do with 'the past's sudden and uncanny interruption or disruption of the present' (Gordon 2008). In conjuring the Jewish undead to make the circumstances of their murder and dispossession known, Polish Holocaust horror signifies an intervention into a memorial landscape characterised by what Erica Lehrer has called 'traditional and divisive historiography' prior to the last two decades, in which Jewish Holocaust narratives were obscured and subsumed by dominant Polish ones (Lehrer 2013).

Picart and Frank relate Holocaust horror to the ghostly yet realistic taxonomies of the Gothic, a specific strand of horror concerned, among other things, with haunting, transgressions and monsters. For both critics, the presence of monsters that 'breach the norms of ontological propriety' is a defining feature of horror, yet the function of these monsters alters depending on whether they are situated within what they call the 'classic' or 'conflicted' horror frame (Picart and Frank 2006). While the former relates to early Hollywood cinema, in which monsters are so completely other that they must be overcome via killing, the latter, as Picart and John Edgar Browning explain, views evil as 'residing alongside the 'normal" (Picart and Browning 2012). Polish Holocaust horror instrumentalises a framework of conflicted horror, characterised by a being-with, rather than an overcoming of, the dead. And yet the 'monsters' of this genre, if we can call them this at all, are not evil in and of themselves, but rather expose the work of evil or horrific misdeeds. Whereas Americanised Holocaust cinema has often involved depictions of Nazis-as-monsters, or of Nazism as a profoundly corrupting force of evil, the monsters encountered within this nation-specific genre are configurations of memory, 'those who have perished or disappeared-revenants, the undead or ghosts of the past' (Dziuban 2014). Iterations of the returning Jewish repressed are thus diverse, with ghosts, spectres and reanimated bodies mingling within the genre, figures that serve the same memorial purpose despite their varied

2 This is the translation used by Roma Sendyka in her presentation 'Researching Non-sites of Memory' at the Sites of Violence and their Communities: Critical Memory Studies in the Post-Human Era conference, Jagiellonian University, Kraków, on 24 September 2019. 
appearances. What distinguishes these haunting mechanisms most, then, is exactly how they are summoned within the genre. Assmann claims that while spirits are conjured or called up, ghosts 'intrude' and come 'without bidding' (Assmann 2011). Yet all agents of haunting in Polish Holocaust horror, including the zombified corpses that swarm in Igor Ostachowicz's 2012 novel Night of the Living Jews, are unwanted reminders of a traumatic past that intrude, uninvited, into the present. While spectres or revenants are conjured into existence by the genre, ghosts materialise or appear, and reanimated corpses are corporeally resurrected. As Psycho's Norman Bates shows us, however, horror pivots not on the monstrosity of its monsters, but rather on its reminder that 'the true monster resides inside us' (Picart and Frank 2006). This notion is rooted in nineteenth-century thought, where, Andrew Smith claims, 'there is a progressive internalisation of horror, the idea that monsters are not out there [emphasis my own] but to be found within' (Smith in (Cochrane 2013)).

This sentiment is also embedded within the classic 1960s horror films of George Romero, whose cinematic summoning of the undead is inextricably linked to the returning Jewish motif. For, the late Night of the Living Dead (1968) director insisted that his films are not about zombies but all about '[un]dead neighbours', an altogether more sinister lens through which to view the violent encounters staged within his work, precisely because they take place between those who are intimately connected, whether zombified or otherwise (Romero in (Weston 2019)). This tension is indicative of why the concept of neighbours, the eponymous subject of Gross's aforementioned work, has become synonymous with current Holocaust debates regarding wartime Polish behaviour despite its ambiguous meaning. Referring both to the self-sacrificing aid given to Jews by Polish rescuers on the one hand, and to the relation of some Jews to their Polish murderers on the other, inscribed within this term is a simultaneous process of proximity and distancing. Critiquing the implicit requirement of western multicultural ideology to 'tolerate', rather than authentically accept the other, Slavoj Žižek conceptualises the neighbour in opposition to the biblically-rooted refrain 'love thy neighbour as thyself' (Žižek 2010). As an ideology of tolerance rather than benevolence, Žižek sees this biblical commandment as emblematic of the ways in which the other is 'objectivised' in society, a means of humanising and superficially understanding the other which treats their proximity as intrusive and prevents them from getting 'too close' (Ibid. 2010). The motif of the returning Jew enacts this neighbourly intrusion via haunting, which has forced the Polish population to view themselves as perpetrators, as well as victims of, the Holocaust.

The popularity of Holocaust horror in Poland parallels that of the culturally enduring Gothic figures of the ghost and the zombie to which they are related. Simply put, the zombie can be described as a fleshy being lacking consciousness, the ghost a form of consciousness lacking bodily containment. It is for this reason that ghosts are often associated with memory and history, making them ripe symbolic outlets for twenty-first century Polish concerns relating to the remembering and forgetting of the nation's past. As uncanny reflections of the self, zombies more clearly embody fears regarding the relation of oneself to the unknown other and have most famously been deployed to such ends in Romero's work. The aforementioned and culturally constructed antisemitic stereotypes connect Jewish people with the necropolitical instability of ghosts and zombies, neither of which are 'alive' per se, characterised rather by their definitional ability to blur the boundaries between life and death. Moreover, these stereotypes are products of the logic that keeps the neighbour close and at arm's length, a mechanism that deems others to be monstrous precisely because they are not so different from ourselves. Pasikowski's film signifies an important addition to Poland's experimental canon of Holocaust cultural production as it instrumentalises the fundamental aspects of both ghostlike or spectral subjectivities (their evocation of the post-traumatic world) and reanimated corpses (their ability to show a mirror image of the other to oneself), to challenge the official image of Poland as a nation of victims and heroes. The murdered Jews of Pasikowski's Aftermath are embodied in the first instance by a spectral presence which haunts the film, and in the second, by its protagonist Józef, who becomes (at least metaphorically) a reincarnation of the Polish Holocaust Jew persecuted and ultimately 
murdered for his falsely attributed 'Jewish' identity. We thus encounter spectral and corporeal 'Jewish' life in Pasikowski's work, though the latter is particularly ambiguous.

\section{The Spectral Gaze of the Undead}

Reigniting the controversy that surrounded Neighbours, Pasikowski's film is convincingly set in provincial Poland in 2001 and deals with the residual antisemitism of its Polish residents, who have been keeping secret the murder and dispossession of their Jewish neighbours in a wartime massacre similar to Jedwabne. Aftermath traces the reuniting in Poland of formerly estranged brothers Franek (Ireneusz Czop), a construction worker living in Chicago, and Józef Kalina (Maciej Stuhr), a farmer tending to his family's land in an unidentified agricultural Polish village. Józef, the younger of the brothers, is lynched by his community for vandalising a public road by ripping up the gravestones of Polish Jews and rearranging them in a makeshift cemetery in one of his fields. While the casually antisemitic Franek is initially disapproving of his brother's commemorative efforts-which, significantly, are only ever justified by Józef via the words 'they were human beings' - he comes to aid Józef's campaign as his investigation of the past exposes the central role their own father played in the massacre (Pasikowski 2012). Met with brutal hostility by the rural Poles he lives among, Józef endures beatings, the vandilisation of his property, the murder of his dog, and the setting alight of his crops as punishment for his attempt to deliver memorial justice to the slaughtered Jews of his village.

According to the author of Neighbours, 'one day in July 1941, half of the population of a small East European town murdered the other half-some 1600 men, women and children' (Gross 2012). Challenging standard historiography concerning Polish-Jewish wartime relations, Gross's work has been both demonised and hailed by individuals and institutions for its contentious portrayal of Poles as perpetrators, who, emboldened by a Jewish-hating Nazi campaign, beat their Jewish neighbours with home-made weapons and burnt them alive in a barn. While this slaughter was no singular occurrence-Sara Bender (Bender 2013) cites the mass murders in nine additional Jewish communities in serial pogroms in the Łomza and Grajewo district in the days following Operation Barbarossa-Gross writes that the events of the Holocaust in Poland have been 'bracketed by historians as a distinct, separate subject that only tangentially affects the rest of Polish society' (Gross 2012). By subjecting a non-Jewish Pole (in the film and in reality) to the kinds of suffering enacted against Jews by some of their Polish neighbours, including the eventual crucifixion of his protagonist, Pasikowski implicates Polish society at the very nucleus of these events. Yet this narrative inversion of ethnic Poles and Jews has, as in the film, led to a reproduction of antisemitic abuse targeted particularly toward Stuhr for his role as a Pole sympathising with Jews.

Engendering an impending sense of dread that culminates in Józef's exhumation of Jewish bodily remains on his father's original land and his untimely death, the horror of Aftermath hinges on an intensely figured claustrophobia which comes to define much of the rural town and its inhabitants. Manifesting primarily in the intuitive and familiar feeling of being watched by another, Franek is overcome with an unexplained paranoia from the very moment he arrives in his home town - which is for the first time in twenty years. Fuelled from the film's opening by tracking shots that stalk Józef's 'long-lost American brother' through the Polish forest as he investigates a strange noise from within (see Figures 1 and 2), the camera itself becoming the undead subject, Pasikowski immediately alerts his audience to the fact that this place is imbued with some intangible yet omnipresent form of life. Producing the disorientation and consuming fear often accompanying forest horrors (The Evil Dead (1981); The Blair Witch Project (1999)), this land appears not only to be alive per se but betrays a distinct hostility to those-like Franek-who dare occupy it. The anthropomorphic undergrowth cracks around the eldest Kalina brother, who stumbles through the dark trees with panic. Intensified via the repetitive non-diegetic drone of Jan Duszynski's score, the encircling camera drives Franek deeper into the forest, where an ominous green hue owing to the enmeshed canopy of leaves above gives the impression that he has entered another realm. Punctuated by silences that give way to the diegetic echo of distant birds and heavy breathing, these ominous drones continue to encroach upon Franek with increasing 
pace, until finally he breaks into a run and is knocked to the earth by an unnoticed branch, where he stays, unconscious, until nightfall.

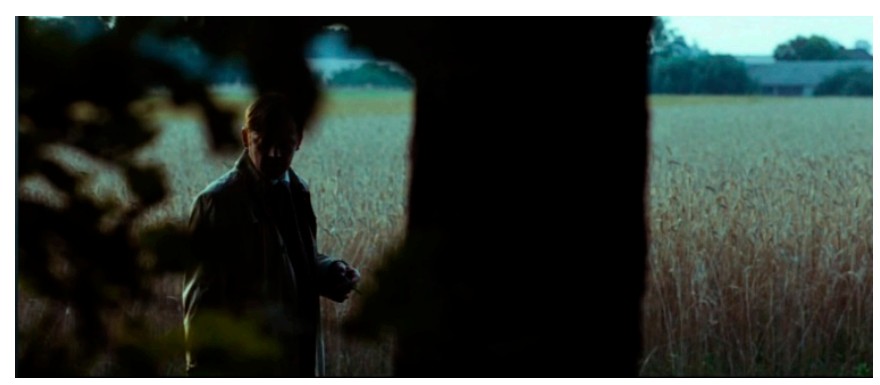

Figure 1. Franek seen from the woods.

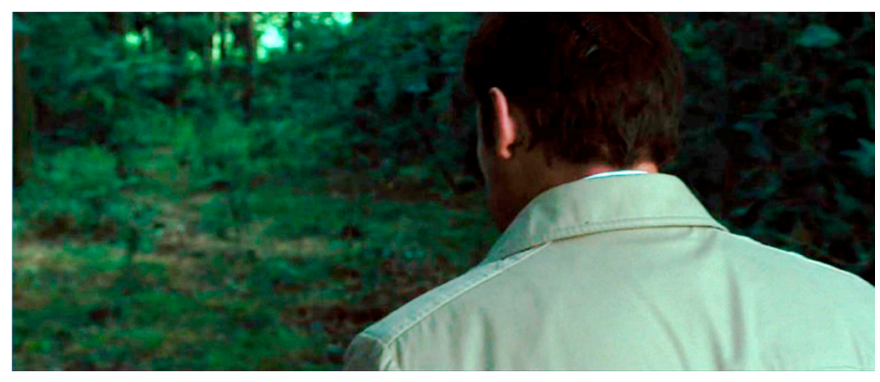

Figure 2. Franek investigating a noise from within.

The vitalisation of vegetative life (and trees in particular) by this seemingly hostile spectral presence gestures toward the existence of some past corruption linked inextricably to the land, lending Pasikowski's rural universe an engulfing air of dis-ease. For, unbeknown to the unsuspecting viewer and to Franek himself at this stage in the film, Jews return within Polish Holocaust horror to haunt the very spaces where violence was committed against them. Illustrative of forested sites of mass killing in central and eastern Europe, Pasikowski's use of the forest is particularly divisive due to its invocation of the 'long, well-documented, and close connection' that, as Brett Ashley Kaplan points out, 'binds the wooded landscape to German fascism' (Kaplan 2008). Having borne witness to such wartime killing, the Polish forest - a site of wartime shelter, resistance and natural solace as well as a fascist icon-here becomes a memorial landscape reclaimed by the lives of those whose murder and dispossession have yet to be fully acknowledged, let alone commemorated by, the very people responsible. Affirming the animate status of Jewish-haunted landscapes in Poland, Roma Sendyka names these memorially deficient and unconsecrated spaces of Jewish killing 'active' or 'non-sites', sixty per-cent of which are currently abandoned and unprotected in Poland despite their proximity to Polish life (Sendyka 2019). Not only 'vicarious bearers' of historical trauma (Ibid. 2008), Dawn Keetley and Angela Tenga in their book Plant Horror write of the 'alien and inimical' nature of plants, bushes and trees, which exist in 'the outer limits of what we know' and thus embody 'an absolute alterity' (Keetley and Tenga 2016). Inherently connected with the uncanny yet unknowable quality of the monstrous other, plant life is itself ontologised as vengeful in this sequence, interacting with spectral Jewish life to form what Matilda Mroz calls a 'network of spectral looking' that haunts Franek and his town (Mroz 2016). These hostile ontologies exemplify the fact that, aside from its reconciliatory function, haunting in contemporary Polish Holocaust fiction also enacts what Magdalena Waligórska describes as 'a form of punishment, retaliation, and vengeance' (Waligórska 2014).

While the inscription of past Jewish life within a present-day material environment grants collective (if hostile) subjectivity to those to whom the land and homes now occupied by the Polish townsfolk once belonged, this spectral presence is defined precisely by its absence. As demonstrated by Franek's extrasensory impression of being watched over by that which he cannot see, the spectral encounter is always characterised by what Jacques Derrida calls the 'visor effect'; the idea that 'This 
Thing [ ... ] looks at us and sees us not see it even when it is there' (Derrida 1994). Distinguishable from the ghost, which manifests as a nebulous bodily apparition, the revenants of Derrida's Spectres of Marx constitute 'the tangible intangibility of a proper body without flesh, but still the body of someone as someone other' (Ibid. 1994). Defined by this 'supernatural and paradoxical phenomenality', the spectre is thus felt but never seen. Horror consists precisely in this moment when the gaze of the subject is returned unseen, what Mroz calls 'blind spots', which extend to the viewers of Aftermath who are denied explicit indicators of whom or what haunts Franek. In order to expose the film's source of spectral looking, Mroz brings this performative process into productive dialogue with the concept of anamorphis. Mroz traces cinematic anamorphis, a foreign or uncanny disturbance of an otherwise undisturbed visual field, in the antisemitic graffiti painted on the village bus stop where Franek first arrives, which is given little credence by the camera or indeed by Franek himself. The graffiti, which depicts a Star of David hanging from a gallows below the words 'Żydy won'3 ('Jews piss off'), signifies 'a cinematic structuring of a blind spot' that the film works to make-visible via haunting (Mroz 2016).

Polish Holocaust horror is all about the creation of these blind spots, which in Aftermath, Mroz demonstrates, address and actively implicate the viewer. A supernaturally rendered life form, the fundamental contradictions that characterise the spectre-visible/invisible; sensuous/non-sensuous; tangible/intangible; self/non-self-are also crucial to understanding the functioning of the Jewish other in specific historical as well as cultural European contexts. The spectralised presence of the Polish-Jewish other in Pasikowski's fictional town invokes both the traces of a lost community and pertains more broadly toward what Karen Underhill terms Poland's 'spectral Jewish past' - that which, linked inextricably to Jewish exile, settlement and repatriation, is rooted in a vexed geographical and territorial dynamic of presence and absence (Underhill 2016).

\section{Spectral Jews}

Not only have contemporary Jews been physically and culturally absent from the Polish spaces Jewish people once occupied, Steven F. Kruger (Kruger 2006) explains in his study of The Spectral Jew that Jewishness and Judaism have always been subject to the erasure of spectral othering since the arrival of Jews in medieval Western Europe. Contributing toward a continued mythologising of the Jewish other as simultaneously apparitional yet embodied, over centuries, Sara Libby Robinson claims, 'Jews have emerged as Christianity's religious vampires, their supposed misdeeds tied to the misuse and consumption of Christian blood' (Robinson 2011). Accusations of blood-libel (the claim that Jews murdered gentiles, especially children, for the ritual use of their blood) fuelled this defamatory conflation of Jews with vampires, as though kosher laws bring the idea of bloodletting to mind, which helped pathologise ostensibly 'Jewish' features well before Nazi eugenics and reduced Jews to lustful, parasitic monsters. In this way, the Gothic figure's bloodsucking nature vilifies the immortal and mythologised notion of Jews as wandering; a people without a homeland who feed off other nations. This resonates with what Simon Enoch calls 'medical discourses of purity and infection' surrounding recent Polish Holocaust debates, at the centre of which is the idea that (past) Jews are somehow contaminating the 'otherwise healthy' body politic of Poland with unwanted memories that disturb the image of Polish martyrdom (Enoch 2004).

This designation of a corrupted body to the culturally envisaged Jew constitutes an effort to contain the Jewish other and mask the fleshy animality of the self, resonating with Derrida's assertion that the spectre only 'appears to be present itself during a visitation. One represents it to oneself, but it is not present, itself, in flesh and blood' (Derrida 1994). Thus Franek's instinctive response to the spectral presence that accompanies him in the Polish forest is to humanise it: he enters the trees in search of a tangible, physical being (hence his choice of a branch for protection), yet the necropolitical status of the spectre, permanently caught between life and death, ensures that it cannot be banished. The fixed

3 This is the translation used by Matilda Mroz in the corresponding publication. 
gaze of this absent Jewish presence is reproduced by the rural townsfolk who watch closely over the Kalina brothers with equal hostility—directed mostly (but not exclusively) at Józef-for reasons that remain unclear to Franek until the film's narrative climax. These residents make their dislike of Józef apparent from Franek's very first encounters with them, yet Józef remains silent about his 'antisemitic' victimisation and the fact that he ripped up 328 Polish Jewish gravestones reinforcing an old road.

\section{Rescuing Matzevot}

Used as 'thresholds, work surfaces, flagstones' and even appearing in Filipowski's outhouse within the film, the destruction and displacement of gravestones by Nazis who tore up synagogues and cemeteries during the war constituted one of the very first steps in the erasure of Jews from collective memory in Poland (Pasikowski 2012). Here, James E. Young argues, 'just about every shtetl cemetery was either destroyed by local Nazi officials (who plundered the stone for paving projects) or abandoned (and often later desecrated) by local Poles looking for treasures' (Young in (Ezrahi 2017)). The absence of any comprehensive national drive to rehabilitate Jewish gravestones from buildings and urban spaces in post-war Poland, whether owing to ignorance, neglect or the post-war anti-religious communist era, facilitates the preservation of an anti-Jewish hierarchy built into the local landscape. Much like Stolpersteine, the memorial stumbling stones installed in European city streets to locate and identify Nazi victims, these gravestones are walked and driven over daily, subsumed by everyday life.

There have, however, been a number of local restoration initiatives-throughout the 1980s, Henryk Grynberg points out, as well as post-1989-to salvage and return these gravestones to the Jewish cemeteries in which they belong, despite broader governmental inaction (Grynberg 1997). A city-funded project launched in Warsaw in 2014, for instance, returned 1000 stones used to construct a pergola and stairway inside a recreational park in Warsaw's Praga district to the Brodno Jewish Cemetery, where a permanent exhibition opened last year on Jewish funeral traditions. Monuments have also been made of these rescued gravestones in Poland, with broken tombstones being rearranged into what Young calls 'tombstone memorial obelisks' in Krakow, Warsaw and Kazimierz na Dolny, 'usually by post-war Jewish returnees to their hometowns, but occasionally also by local Polish youth groups' (Young in (Ezrahi 2017)). As physical counterparts to the spectral Jewish presence haunting Aftermath, the central role of these matzevot (the Hebrew term for tombstones or monuments) in the film helps ground in the material world the otherwise traceless victims of what Andrea Petô calls a 'nameless event', despite the fact that they are presumably those of pre-war Jews (Petó 2019).

Exposing the fact that National Socialism did not discriminate between the living and dead when it came to annihilating European Jews, the separation of these stones from their corporeal remains also violates the sanctity of an aspect of Jewish law that, Rabbi Geoffrey Dennis argues, is taken 'quite seriously' by most Jews (Dennis 2013). Kavod ha-met, or 'showing respect for a corpse', he writes, is why Jews prefer not to display their dead in open-casket ceremonies, why they do not embalm, and why they are 'fastidious' about collecting all parts of the body for burial (Ibid. 2013). Griselda Pollock has argued that there can be 'no more profound assault on a human subject than the deprivation of a person of his or her proper treatment after death in terms of cultural conventions of burial, cremation, or other designated rituals that ensure that the end of organic life is treated as a human event' (Pollock and Silverman 2019). Reifying the film's theme of the returning Jewish undead, the relocation of these stones to a place of safety is a quasi-restorative, humanising act. Planted in Józef's field (see Figure 3), these matzevot draw attention to the unmarked ravines and fields containing Jewish bodily remains in rural Poland, which for Sendyka require a change in nomenclature from mass graves to 'Jewish pits' or 'corpse fields' - terms that acknowledge their lack of religious ritual and closure (Sendyka 2019). 


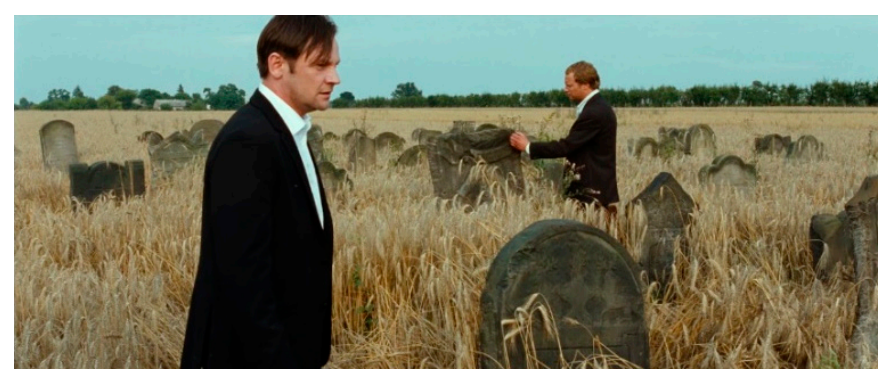

Figure 3. Józef showing Franek his make-shift Polish-Jewish cemetery.

Józef's protection of the stones is motivated, however, by a largely ineffable and internalised moral drive. The motif of the returning Jew has been branded 'elitist' by some scholars, like Lehrer, in the knowledge it assumes of its viewer about the complexities surrounding national debates over wartime Polish conduct, and the place of such debates in contemporary Polish culture (Lehrer 2013). Józef's inability to express his incentive for protecting the stones other than through a feeling that he 'had to', however, is simple (Pasikowski 2012). Untouched by sentimentality or romanticism, Józef's memorial campaign exemplifies the fact that one need not be educated nor Jewish to be able to mourn for and remember the Jewish dead in Poland, for it is also Józef, the uneducated brother, who continually corrects his cosmopolitan brother's use of 'Yids' to 'Jews' (Ibid. 2012). In his interview with the film's director, Leonard Quart argues that Pasikowski 'never tried to magically turn the inarticulate Józef into someone who can explain why he is so committed to providing justice for the Jewish dead', though Mroz seems to attribute Józef's, as well as Franek's later motivation to the film's spectral Jewish presence (Quart 2013). In this way, the film advocates for the participation of Poles in the darker aspects of its Holocaust history via commemorative action, as an alternative to engaging with what Antony Polonsky calls a 'scholarly debate only interacted with by scholars' (Polonsky 2019).

\section{Józef-as-Christ}

Sharing the religious identity of those who seek to denounce and ostracise him, Józef and his brother's Catholic faith makes their antisemitic persecution by their townsfolk particularly ironic, and at times ambiguous. Alluding to hostile Polish-Jewish relations during the Holocaust, the escalation of antisemitic acts of violence toward Józef and Franek by these Catholic neighbours exposes the hypocrisy not just of perpetrators, but also of collaborators, bystanders and descendants whose religion dictates adherence to the fundamental doctrines 'love thy neighbour as thyself' and 'thou shalt not kill'. And yet these Judao-Christian laws, Derrida argues in 'Eating Well', are not universal, for they have never been understood as " Thou shalt not put to death the living in general"', but the human specifically (Derrida 1995). Hence, they become defunct when dealing with cultural paradigms of the undead Jewish other. This sheds important light on the insufficient wartime resistance of the Catholic Church to Nazism, even as Jews were being deported to death and labour camps from Rome, for which a papal apology was delivered by the Polish-born Pope John Paull II in 2000. Forgiveness was also asked by Polish bishops in 1995 for the 'indifference' and enmity demonstrated by Poles toward their Jewish neighbours during the war on behalf of the Catholic Church in Poland, which never publicly denounced Jewish persecution during the German occupation (Dulles et al. 2001). The most disturbing and visceral instances of 'antisemitic' violence in the film, notwithstanding Józef's murder, include the protagonist's unprovoked beating in a bar and the decapitation of his dog Burek. Precursors to Józef's death, these gruesome sequences reflect what Gross names the 'primitive, ancient methods' deployed by Poles in the humiliation and beating of Jews during the Jedwabne massacre, and indeed in violent antisemitic attacks throughout central-eastern Europe at this time (Gross 2012). As such, Józef's beating signifies an inversion of the wartime anti-Jewish assaults perpetrated by his own father, who, he learns nearing the film's close, beat a young Jewish woman to death for rejecting his affections and lit the fire that killed the remaining Jews of the town. 
While other Holocaust works dealing with the bloody reality of complicity and collaboration on Polish soil exist, such as Słobodzianek's play Our Class (2008), Aftermath was the 'first Polish fictional film to depict Poles committing violent acts against their Jewish neighbours during WWII' (Quart 2013). Though his depiction of Catholic Poles as brutal anti-Jewish peasants and descendants of murderers has caused much backlash in Poland since the film's release in 2012, Pasikowski's deconstruction of a national self-image built almost exclusively upon heroism and martyrdom is nonetheless radical. Perhaps the most significant source of controversy relating to the film concerns its explicit inversion of Polish Holocaust martyrdom: the crucifixion of Józef by unknown (but local, it is assumed) assailants. In the image of Józef-as-Christ, hanging from a crucifix on a barn door (see Figures 4 and 5), Pasikowski self-reflexively refers to the notion of Poland as what Elzbieta Durys has called a 'Christ of nations', a paradigm which periodically resurfaces in Polish culture and emphasises the fact that Poland suffered to 'redeem and bring salvation to the nations of Europe' (Durys 2017). Although the severity of Polish death and suffering during the Nazi occupation must not be downplayed, Pasikowski's ironic reversal of non-Jewish Polish martyrdom, in which Poles are not the crucified but the crucifiers, critiques its dominance as a symbol of national identity preventing Poland from self-criticism and the inclusion of Polish-Jewish voices into official narratives of remembrance.

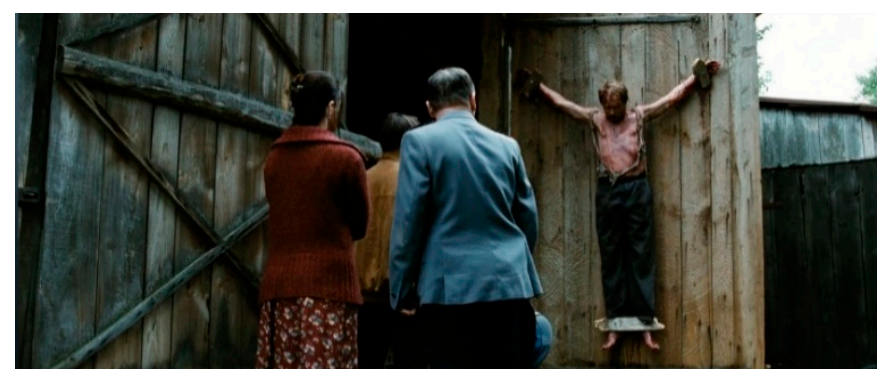

Figure 4. Townsfolk investigating Józef's crucified body.

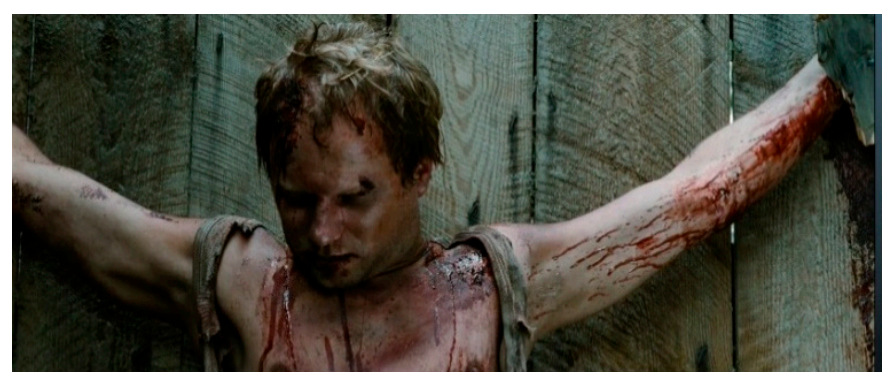

Figure 5. Close up of the above.

Aside from critiquing Polish constructions of martyrdom, the religious connotations of Józef's murder, foreshadowed by the film's early image of a hanged Star of David, are ambivalent. In one sense, Józef's crucifixion marks his full transition in the present into the murdered Jew of the past: here, Józef embodies each of the 6 million persecuted Jews slain for their identity, be it due to religious or racial antisemitism, or the kind of affronted male pride and personal spite that leads Józef's father to commit mass murder. Paradigmatic of Gross's use of neighbours, the fact that Józef is murdered by a member of his town exemplifies his betrayal and affirms the idea that what is most horrifying about horror fiction and film is the transgressions of those with whom we are most familiar. This becoming-Christ through murder also enacts a reversal of the anti-Jewish doctrine of the Catholic Church that claimed Jewish responsibility for the murder of Jesus, which was 'said to have ideologically underpinned Nazism' despite the wartime persecution of the church itself (Carroll 2000). Such messianic imagery places emphasis on understanding Jewish persecution as central to achieving contemporary Polish-Jewish coexistence yet brings with it a long trajectory of Jewish suffering that 
casts a sinister light on Pasikowski's metaphor, which seems to suggest the divine redemption of Poles now that the sacrificial killing of Józef-as-Jew has taken place.

This appropriation of religious history via popular culture has also been understood as blasphemous by Poles, a response that constitutes one of the two 'types of allegations' Pasikowski faced for his representation of Józef's death, the other being the improbability of the crucifixion itself (Durys 2017). Particular criticism came from right-wing Polish nationalists who, according to the producer Dariusz Jablonski, 'accused the film of being part of a Jewish conspiracy to tarnish Poland's reputation' and directed much of their anger at Stuhr (Józef), who received death threats for being 'a Jew and not a Pole anymore' (Quart 2013). Motivated by a similar moralistic drive to that directing Józef, Jablonski defends the intentions of the film as a telling of 'the truth to one's own nation, rather than being a portrait of Poland as antisemitic' (Ibid. 2013). Such responses from critics and Polish media outlets of the right exhibit the active presence of anti-Jewish hostility still in Poland, where acts of antisemitic vandalism and violence are increasingly commonplace and the multicultural past is threatened by a 'rightward and nationalistic turn' (Smale 2016). While the motif of the undead or returning Jew signifies a collective attempt to move away from continued wartime antisemitism and recent hegemony, it has the potential to re-bury Poland's dark past, reflected in the work of Pasikowski's villagers, who go to extreme lengths to repress their secret and reinstate a life free from accusation and moral disruption.

Yet much positive praise was also generated for the film, which came from high profile figures such as Poland's culture minister, Bogdan Zdrojewski, and the widely read newspaper Gazeta Wyborcza, as well as from local residents who, Pasikowski claims, 'were glad we were telling the truth about that period' (Pasikowski in (Quart 2013)). The first film of its kind to surface in Poland, either due to national shame or state censorship (Pasikowski's bid for state subsidy of the film was rejected several times before he finally secured funding from the Polish Film Institute in 2006), Aftermath deals unapologetically and directly with the plight of Jews during the Holocaust. Even the Kalina brothers' troubled relationship takes a backseat in the film, merely foregrounding the uncovering of the Jedwabne-like massacre, which is central, rather than peripheral, to its narrative plot. As the brothers edge closer to the truth of this unspoken village secret with Franek's discovery of archival evidence that the land of the villagers was stolen from Jewish farmers during the war, the film's metaphor of digging up the past culminates in what Graham Fuller names two 'sub-Gothic nocturnal sequences': the physical disinterment of the remains of Jews murdered by members of the village who remember the pogrom and the removal of Jewish gravestones from the church, as sanctioned by the parish priest, who deems them to be doing the work of God (Fuller 2013).

In the former, and more disturbing of these sequences, Józef and Franek dig up the remains of those murdered by their own father from the marshland on his original pre-war plot-a physical as well as figurative tearing open of a hidden grave that had been sealed for sixty years prior (see Figure 6). In this depiction of Józef's final act for which he will be punished, the fictional post-communist Poland becomes a nightmare realm comprising of traumatic flashbacks to the events of its own past. Here, the camera reassumes its undead gaze, looking down upon this gruesome scene from above and drawing the viewer's attention back to the presence of the spectral Jew, whose bodily remains are finally uncovered. Conceiving of Pasikowski's Jews as 'both scary spectre and classroom prop', Uilleam Blacker suggests that the film calls upon the Jewish undead to teach Poles a lesson, before sending them away again (Blacker 2016). Rather than bringing closure, however, Pasikowski's restoration of the spectral Jewish perspective exemplifies the fact that the Kalinas' exhumation subjects these undead Jews once more to necropolitical life via the violation of Jewish interment rituals. 


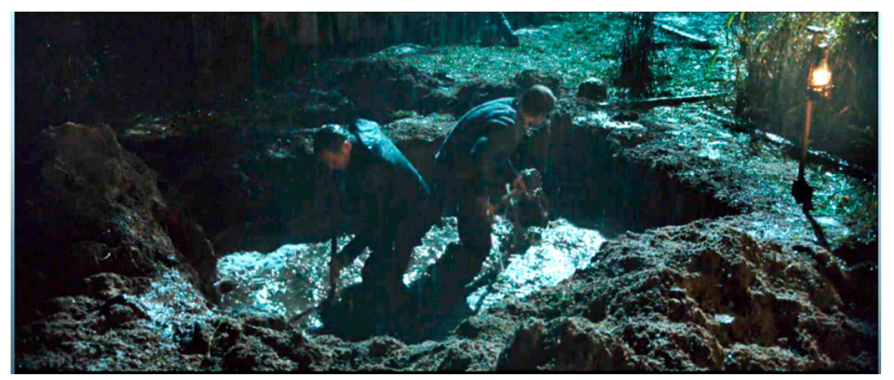

Figure 6. Franek and Józef exhuming the remains of the wartime Jews murdered by their father.

\section{Conclusion}

Repeating itself in posttraumatic fashion with this upheaval of Jewish remains and the murder of Józef as 'Jew', history haunts this town, and yet the town evades historicity, its namelessness preventing direct associations with Jedwabne. As such, Aftermath offers neither moral redemption to its villagers, nor a resolution to Józef's campaign to draw attention to the murdered Jews of his village, the transformative potential of which is never fully realised since this secret is quickly reburied. In the final scene of the film, Orthodox Jews travel to Józef's Polish-Jewish memorial to say Kaddish, where Franek, transformed by his brother's consideration for the Jewish other (or the spectral Jew), lights a candle on the gravestone of one who does not belong to 'his' people. Uniting a Polish with a Jewish commemoration, Józef succeeds in his creation of a Jewish cemetery in Poland that physically commemorates the pre-war Jews of his town, and which metaphorically commemorates those murdered at the hands of his father and his Polish accomplices. The inscription on the memorial stone marking the cemetery, however, bears no mention of the rescue of the stones, or the history of this village as it relates to the Holocaust, simply reading 'To the memory of those buried on this spot' (Durys 2017). Durys compares this to the inscription of the official Jedwabne memorial, which she translates as 'To the memory of Jews from Jedwabne and the surrounding area, men, women and children, co-habitants of this land, who were murdered and burned alive on this spot on 10 July 1941' (Ibid. 2017). Significantly, neither explicitly mentions the Polish nationality of those who committed these murders, which consequently remain unreconciled.

Despite performing a violence against Jewish Holocaust victims, Aftermath's ultimate concealment of Polish perpetrators and re-establishment of the undead Jewish gaze ensures that this memorial work is unfinished, and, as such, prevents the absolution of Polish responsibility for their role in wartime antisemitic murder and dispossession. The fact that the space opened for developing Jewish Holocaust memory by Józef's death is not filled by the villagers also serves as a critique of the broader cultural movement of the so-called 'Jewish Renaissance' in Poland, which, Pasikowski seems to suggest, might do well to focus more on direct commemorative action, such as the rescuing of matzevot, rather than re-mystifying Jewish life and culture. Quoting Jo Labanyi, Mroz points out that Aftermath deploys haunting in a way that 'elides direct representation of the past in favour of the representation of its aftereffect', to which the film's title testifies (Mroz 2016). Paradigmatic of Polish Holocaust horror, Pasikowski's film is thus orientated toward the future despite its upheaval of the traumatic past: like the spectre that 'always begins by coming back', Aftermath implicates the Polish nation in a cyclical return to Polish-Jewish memory (Derrida 1994).

Funding: This research was funded by the University of Sheffield via the White Rose College of the Arts \& Humanities.

Conflicts of Interest: The author declares no conflict of interest.

\section{References}

Pasikowski, Władysław. 2012. Aftermath. Warsaw: Monolith Films.

Assmann, Aleida. 2011. Ghosts of the Past. East European Memory Studies 8: 1-5. 
Assmann, Aleida. 2018. Erinnerungsräume: Formen und Wandlungen des kulturellen Gedächtnisses (1999) Geisterorte. Munich: C.H. Beck.

Bartana, Yael. 2010. The Manifesto of the Jewish Renaissance Movement in Poland. Available online: http: //www.jrmip.org/?page_id=5 (accessed on 12 August 2019).

Bender, Sara. 2013. Not Only in Jedwabne: Accounts of the Annihilation of the Jewish Shtetlach in North-Eastern Poland in the Summer of 1941. Holocaust Studies 19: 1-38. [CrossRef]

Blacker, Uilleam. 2016. The Return of the Jew in Polish Culture. In Reverberations of Nazi Violence in Germany and Beyond: Disturbing Pasts. Edited by Stephanie Bird, Mary Fulbrook, Julie Wagner and Christine Wienand. London: Bloomsbury.

Carroll, Rory. 2000. Pope Says Sorry for Sins of Church. Available online: https://www.theguardian.com/world/ 2000/mar/13/catholicism.religion (accessed on 7 February 2019).

Cochrane, Kira. 2013. Ghost Stories: Why the Victorians Were So Spookily Good at Them. The Guardian Online. Available online: https://www.theguardian.com/books/2013/dec/23/ghost-stories-victorians-spookily-good (accessed on 29 September 2019).

Dennis, Geoffrey. 2013. The Walking Dead: Jews, Judaism and Halloween. Available online: http://ejmmm2007. blogspot.com/2006/10/jews-judaism-and-halloween.html (accessed on 19 November 2018).

Derrida, Jacques. 1994. Spectres of Marx: The State of the Debt, the Work of Mourning and the New International. Translated by Peggy Kamuf. New York: Routledge.

Derrida, Jacques. 1995. "Eating Well”, or the Calculation of the Subject. In Points... Interviews, 1974-1994. Edited by Elizabeth Weber. Translated by Peggy Kamuf. Stanford: Stanford University Press, pp. 255-87.

Dulles, Avery, Avery Robert Dulles, Edward Cassidy, and Leon Klenicki. 2001. The Holocaust, Never to be Forgotten: Reflections on the Holy See's Document We Remember. New York: Paulist Press.

Durys, Elzbieta. 2017. "You want the truth? How do you know you won't choke on it?": The Issue of Memory in Aftermath. In Cultural Studies: Approaches in the Study of Eastern European Cinema. Edited by Andrea Virginás. Cambridge: Cambridge Scholars Publishing, pp. 192-215.

Dziuban, Zuzanna. 2014. Memory as Haunting. HAGAR Studies in Culture, Polity, and Identities 12: 111-35.

Enoch, Simon. 2004. The Contagion of Difference: Identity, Bio-Politics and National Socialism. Foucault Studies 1: 53-70. [CrossRef]

Fuller, Graham. 2013. Digging Up Uncomfortable Truths: Wladyslaw Pasikowski's Aftermath. Available online: https://www.blouinartinfo.com/news/story/979024/digging-up-uncomfortable-truths-wladyslawpasikowskis (accessed on 13 February 2019).

Gordon, Avery F. 2008. Ghostly Matters: Haunting and the Sociological Imagination. London: University of Minnesota Press.

Gross, Jan T. 2012. Neighbours: The Destruction of the Jewish Community in Jedwabne, Poland. New Jersey: Princeton University Press.

Grynberg, Henryk. 1997. Towards a New Jewish and Polish Memory. East European Jewish Affairs 27: 62-64. [CrossRef]

Kaplan, Brett Ashley. 2008. Exposing Violence, Amnesia, and the Fascist Forest Through Susan Silas and Collier Schorr's Holocaust Art. Images 2: 110-28. [CrossRef]

Keetley, Dawn, and Angela Tenga. 2016. Plant Horror: Approaches to the Monstrous Vegetal in Fiction and Film. New York: Palgrave Macmillan.

Kristeva, Julia. 1982. Powers of Horror: An Essay on Abjection. Translated by Leon S. Roudiez. New York: Columbia University Press.

Kruger, Steven F. 2006. The Spectral Jew: Conversion and Embodiment in Medieval Europe. Minneapolis: University of Minneapolis Press.

Lehrer, Erica. 2013. Cur(at)ing History: New Genre Art Interventions and the Polish-Jewish Past'. East European Politics $\mathcal{E}$ Societies and Cultures 27: 510-44. [CrossRef]

Lowenstein, Adam. 2005. Shocking Representation: Historical Trauma, National Cinema, and the Modern Horror Film. New York: Columbia University Press.

Mbembe, Achille. 2003. Necropolitics. Translated by Libby Meintjes. Public Culture 14: 11-40. [CrossRef]

Mroz, Matilda. 2016. Spectral Cinema: Anamorphis and the Haunted Landscapes of Aftermath and The Devil's Backbone. In Haunted Landscapes: Super-Nature and the Environment. Edited by Ruth Heholt and Niamh Downing. London: Rowman \& Littlefield. 
Peto, Andrea. 2019. "Non-Remembering" the Holocaust in Hungary and Poland. In Polin: Studies in Polish Jewry. Edited by Françoise Guesnet, Howard Lupovitch and Antony Polonsky. London: Liverpool University Press, vol. 31, pp. 471-80.

Picart, Caroline Joan S., and John Edgar Browning. 2012. Speaking of Monsters: A Teratological Anthology. New York: Palgrave Macmilln.

Picart, Caroline Joan S., and David A. Frank. 2006. Frames of Evil: The Holocaust as Horror in American Film. Carbondale: Southern Illinois University Press.

Polonsky, Antony. 2019. Overcoming the 'Dark Past': Confronting the Holocaust in Poland, Lithuania and Ukraine. The Ian and Mildred Karten Memorial Lecture. Southampton: University of Southampton.

Pollock, Griselda, and Max Silverman. 2019. Lazarean Sound: The Autonomy of the Auditory from Hanns Eisler (Nuit et brouillard, 1955) to Susan Philipsz (Night and Fog, 2016). In Concentrationary Art: Jean Cayrol, the Lazarean and the Everyday in Post-War Film, Literature, Music and Visual Culture. Oxford: Berghahn Books.

Quart, Leonard. 2013. Breaking National Taboos: An Interview with Wladysaw Pasikowski and Dariusz Jablonski. Cineaste: Amerca's Leading Magazine on the Art and Politics of the Cinema 39: 22-25.

Robinson, Sara Libby. 2011. The Life of All Flesh: Religious Discourse, Anti-Judaism, and Anti-Clericalism. In Blood Will Tell: Vampires as Political Metaphors before World War I. Brookline: Academic Studies Press, pp. $15-42$.

Sendyka, Roma. 2019. Researching Non-sites of Memory. Sites of Violence and Their Communities: Critical Memory Studies in the Post-Human Era. Kraków: Jagiellonian University.

Smale, Alison. 2016. We Don't Need to be Alone: A Political Shift Has Poland Assessing its Values. New York Times. Available online: https://www.nytimes.com/2016/08/11/world/europe/poland-debate-values.html (accessed on 7 October 2019).

Underhill, Karen. 2016. Toward a Diasporic Poland/Polin: Zeitlin, Sutzkever, and the Ghost Dance with Jewish Poland. In Poland and Polin: New Interpretations in Polish-Jewish Studies. Edited by Irena Grudzińska-Gross and Iwa Nawrocki. New York: Peter Lang, vol. 10, pp. 181-96.

Waligórska, Magdalena. 2014. Healing by Haunting: Jewish Ghosts in Contemporary Polish Literature. Prooftexts: A Journal of Jewish Literary History 34: 207-31.

Weston, Hilary. 2019. Dead Neighbours: Jim Jarmusch on George A. Romero. New York: The Criterion Collection. Available online: https://www.criterion.com/current/posts/6426-dead-neighbors-jim-jarmusch-on-george-aromero (accessed on 31 August 2019).

Ezrahi, Sidra DeKoven. 2017. Don't 'Rescue' the Jewish Gravestones Pillaged in Poland. Haaretz. Available online: https:/www.haaretz.com/opinion/.premium-dont-rescue-the-jewish-gravestones-pillagedin-poland-1.5467735 (accessed on 10 January 2019).

Žižek, Slavoj. 2010. Fear Thy Neighbour as Thyself: Antinomies of Tolerant Reason. In YouTube. Boston: Boston University. Available online: https://www.youtube.com/watch?v=K5WNcRoCXCM (accessed on 20 August 2018).

(C) 2019 by the author. Licensee MDPI, Basel, Switzerland. This article is an open access article distributed under the terms and conditions of the Creative Commons Attribution (CC BY) license (http://creativecommons.org/licenses/by/4.0/). 